\title{
Measurement of Anxiety and Depression among HIV Patients seen in the Philippine General Hospital using the Hospital Anxiety and Depression Scale - Pilipino Version (HADS-P)
}

\author{
Deonne Thaddeus V. Gauiran, ${ }^{1}$ Kenneth G. Samala, ${ }^{1}$ Jodor A. Lim ${ }^{2}$ and Ma. Lourdes Rosanna E. De Guzman ${ }^{3}$ \\ ${ }^{1}$ Department of Medicine, Philippine General Hospital, University of the Philippines Manila \\ ${ }^{2}$ Section of Infectious Diseases, Department of Medicine, College of Medicine and Philippine General Hospital, University of the Philippines Manila \\ ${ }^{3}$ Department of Psychiatry and Behavioral Sciences, College of Medicine and Philippine General Hospital, University of the Philippines Manila
}

\begin{abstract}
Background. HIV patients suffer from anxiety and depression but a formal assessment infrequently happens.

Objectives. The study aimed to measure the prevalence of anxiety and depression among HIV patients in UPPhilippine General Hospital.

Methods. This study involving 417 HIV-positive patients used the Hospital Anxiety and Depression Scale - Pilipino version to identify cases, with stepwise regression analysis for correlation.

Results. The prevalence of anxiety, depression, and mixed diagnosis was $10.1 \%$ (0.072-0.130), 3.1\% (0.014-0.048), and $10.8 \%(0.078-0.138)$, respectively. Anxiety was correlated with female sex $(\mathrm{OR}=7.82, \mathrm{Cl} 1.03-59.49)$, unemployment $(\mathrm{OR}=1.76, \mathrm{Cl}$ 0.90-3.42), smoking $(\mathrm{OR}=1.84, \mathrm{Cl} 0.89-3.79)$, homosexuality $(\mathrm{OR}=7.64, \mathrm{Cl} 1.36-42.74)$, and non-use of protective methods during intercourse $(\mathrm{OR}=1.81, \mathrm{Cl} 0.84-3.93)$. Depression was correlated with unemployment $(\mathrm{OR}=2.79, \mathrm{Cl} 0.91-8.54)$ and non-disclosure of status $(\mathrm{OR}=3.04, \mathrm{Cl} 0.79-11.67)$. Mixed diagnosis was correlated to unemployment $(\mathrm{OR}=2.09, \mathrm{Cl} 1.10-3.96)$, smoking $(\mathrm{OR}=2.14, \mathrm{Cl} 1.08-4.25)$, homosexuality $(\mathrm{OR}=3.14, \mathrm{Cl} 0.92-$ 10.65), and non-use of protective methods during intercourse (OR $=1.65, \mathrm{Cl} 0.77-3.53)$.
\end{abstract}

Conclusions. Lower prevalence of anxiety and depression among HIV patients was found in this study compared with other countries. There is, however, a need to allocate resources for screening mental health problems in HIV patients.

Key Words: HIV, anxiety, depression, mental health

\section{INTRODUCTION}

Corresponding author: Deonne Thaddeus V. Gauiran, MD Department of Medicine Philippine General Hospital University of the Philippines Manila Taft Avenue, Ermita, Manila 1000 Philippines Telephone: +63908 8150248

Email: dgauiran@gmail.com
The burden of HIV/AIDS still proves to be a significant challenge. The past years have been witness to the many efforts in decreasing the number of individuals with the said infection through advocacy and education but still 36.7 million (30.8-42.9 million) people are living with HIV all over the world in 2016, raising the total number of cases to 76.1 million (65.2-88.0 million) since the start of the HIV epidemic. ${ }^{1}$ One million (830,000-1.2 million) individuals succumbed to the said infection in that same year. ${ }^{1}$ Since 2010, new HIV infections among adults declined worldwide by about $11 \% .{ }^{1}$ Unfortunately, the same cannot be said for the Philippines. Unlike most countries in different parts of the world, the HIV/AIDS epidemic in the Philippines is 
rapidly growing. ${ }^{2}$ Though the Philippines is still considered as a low-HIV-prevalence country, with HIV cases estimated at 51 per 100,000 adults $(0.051 \%)$, the rise in cases is proceeding at an alarming rate. ${ }^{2}$ In 2013, one HIV case is diagnosed every two hours, coming from an initial estimate of one new case every three days in 2010, with the total estimate number of people living with HIV at 28,072 by the end of the year. ${ }^{2}$ Majority of cases are males (82\%) and belong to the 20-29 years age group (59\%). ${ }^{2}$

The UP-Philippine General Hospital (UP-PGH), through the STD/AIDS Guidance Intervention Prevention Unit (S.A.G.I.P Unit), which was established in 1997, is one of the major centers that cater to STD/HIV/AIDS patients in Metro Manila. It provides care for inpatient and outpatient cases, as well as inter-hospital and interdepartmental referrals. ${ }^{3}$ Over the last year, it has seen a nearly five-fold increase in new cases. Many studies have shown that patients living with HIV/AIDS suffer from anxiety and depression, but most of the time; a formal assessment by a trained physician does not happen, precluding its adequate management. Several scales are currently available in assessing the overall psychological well-being of patients, and one of the most commonly used is the Hospital Anxiety and Depression Scale (HADS). ${ }^{4}$ Early detection of depression should alert the physician taking care of HIV/AIDS patients to promptly refer them to a specialist like a psychiatrist so that a holistic approach in the management of HIV/AIDS is established.

\section{The Hospital and Anxiety Depression Scale}

The Hospital Anxiety and Depression Scale (HADS) is a widely used health-related quality of life (HRQoL) tool for measuring psychological distress. It was developed in 1983 by Zigmund and Snaith in order to screen patients for the presence of depression and anxiety. ${ }^{4}$ It is a 14 -item questionnaire which includes seven questions each on anxiety and depression and can be self-administered. Since its introduction, the said scale has been translated into several languages including one in Filipino, which was recently validated by de Guzman in 2013. ${ }^{5}$

\section{Anxiety and depression among HIV patients}

A report released in 2006 projected that HIV/AIDS and depression are the two leading causes of disability by 2030. ${ }^{6}$ This information has several implications since the two are proved to be interlinked. Several studies have shown that individuals suffering from depression is most likely to exhibit risky sexual behavior and are therefore at greater risk of contracting HIV. ${ }^{7-9}$ On the other hand, a positive HIV test can trigger anxiety and depression in an individual which in turn can lead to unsafe sexual practices and therefore increases the likelihood of spreading the disease. ${ }^{10-12} \mathrm{Also}$, studies have shown that people who have depression are less likely to adhere to their treatment - be it for mental illness and/or treatment for HIV/AIDS. ${ }^{13}$ Therefore, depression proves to be a significant factor in non-adherence to medications and results in poorer health. A study done in 2003 also cited that a significant number of HIV positive individuals who suffer from depression were not officially diagnosed by a trained physician. $^{14}$

This intricate interrelationship between the occurrence of anxiety and depression and the overall health seeking behavior of individuals proves to be an issue that needs to be addressed because of its impact on the well-being of individuals living with HIV/AIDS.

\section{Research question}

What is the prevalence of anxiety and depression among HIV patients seen in UP-Philippine General Hospital using the Hospital Anxiety and Depression Scale - Pilipino Version (HADS-P)?

\section{Significance of the study}

Given the increasing trend of HIV/AIDS prevalence in the country, measures must be done to address the different aspects in the management of patients living with the said illness. Recent years have been witness to the many advances in the treatment of HIV/AIDS, which mainly addresses the physical and biological aspect of its treatment. HIV/AIDS, being an illness that entails a multi-faceted approach in its management requires the physician to not just focus on the physical and biological aspects of the disease but on the mental and psychological aspects as well. Currently, there is no established screening and monitoring program for anxiety and depression among patients of the S.A.G.I.P. Unit of the UP-PGH. The results of this study will emphasize the burden posed by anxiety and depression among HIV patients of the unit. This will hopefully open doors to a formal referral system between the clinic and the Department of Psychiatry of the UP-PGH so that a more holistic approach is achieved in the management of HIV.

\section{Objectives}

The study aimed to measure the prevalence of anxiety and depression among HIV patients seen in the UPPhilippine General Hospital using the Hospital Anxiety and Depression Scale - Pilipino version (HADS-P).

The study also aimed to assess the impact of the following variables on symptoms of anxiety and depression:

a. Demographic (age, sex, and civil status)

b. Socio-economic (highest educational attainment, employment status, and monthly household income)

c. Behavioral (alcohol, cigarette smoking, use of illicit drugs, sexual preference, and use of protective/barrier methods)

d. Psychosocial (extent of disclosure and enrolment in other support groups)

e. Health (use of anti-retroviral therapy and latest CD4 count) 


\section{METHODS}

\section{Study design and setting}

This was a cross-sectional analytic study, which evaluated the prevalence of anxiety and depression among patients diagnosed with HIV at the S.A.G.I.P. Unit of the University of the Philippines - Philippine General Hospital, a tertiary teaching university hospital and assessed the impact of various variables on symptoms of anxiety and depression. The general workflow of the study is outlined in Appendix A.

\section{Study population}

Patients who tested positive for HIV through the S.A.G.I.P. Unit of the UP-PGH were included in the study. Inclusion criteria were being eighteen years or older, who tested positive twice by ELISA tests and confirmed by Western Blot. Patients who did not satisfy these criteria were excluded. Patients who could not understand or speak Filipino were also excluded. Consent could be withdrawn at any time and would not result in any adverse consequences on the part of the participant. Identities of patients were coded to maintain confidentiality. Convenience sampling was used. Patients who consulted at the clinic from June 2014 to August 2014 who satisfied the aforementioned inclusion criteria were included in the study.

\section{Data collection}

Data were collected by the investigators and clinical staff of the S.A.G.I.P. Unit using a pre-determined data collection form (Appendix B) after a written informed consent (Appendix C) had been obtained from study participants.

A sample size of 417 patients was calculated using $80 \%$ power and 0.05 significance level. Logistic regression using binary response variable ( $y=$ anxiety and/or depression) on a binary independent variable ( $\mathrm{x}=$ employment status) detects a change in probability $(y=1)$ from baseline value of 0.575 to 0.425 and corresponds with an odds ratio of 0.546 . An adjustment was made since multiple regression of the independent variable of interest on the other independent variables in the logistic regression obtained an $\mathrm{R}$-squared statistic of 0.20 .

Data on demographic, socio-economic, behavioral, psychosocial, and health variables were collected using the data collection form and a review of medical records. Demographic data (in Filipino) were filled out by each study participant while the socio-economic, behavioral, psychosocial, and health data were filled out by the researchers. Demographic variables included age, sex, and civil status. Socio-economic variables included highest educational attainment, employment status, and monthly household income. Behavioral variables included use of alcohol, cigarette smoking, use of illicit drugs, sexual preference, and use of protective/barrier methods. Psychosocial variables included extent of disclosure and enrolment in other support groups. Health variables included anti-retroviral therapy and latest CD4 count.
In this study, symptoms of anxiety and depression were measured using a validated Filipino translation of the selfadministered Hospital Anxiety and Depression Scale, also known as the Hospital Anxiety and Depression Scale-Pilipino Version (HADS-P). The scale is composed of seven items on depression (Items 1 to 7 ) and seven items on anxiety (Items 8 to 14 ) and each item contain four (0 to 3 ) response options. The subscales measure anxiety and depression with a range from 0 to 21, with a higher score denoting greater number of symptoms of either anxiety or depression. Specifically, scores of 0 to 7 in each subscale corresponds to a non-case, scores of 8 to 10 corresponds to a borderline case and scores of 11 to 21 corresponds to a case. Administration of the HADS-P took about two to five minutes.

\section{Analysis}

STATA version 12 was used for the statistical analysis. Descriptive statistics of the HADS-P anxiety and depression measures were generated with the aim of assessing the prevalence of anxiety and depression in the study population.

Prevalence was calculated using the following formula:

$$
\text { Prevalence }(\%)=\frac{\text { Number of identified cases }}{\text { Number of tested patients }} \times 100 \%
$$

The descriptive statistics of the demographic, socioeconomic, behavioral, psychosocial, and health variables were also compiled. Continuous variables such as age and CD4 counts were presented as means and standard deviations. Categorical variables such as sex (male vs female), civil status (single vs married/co-habiting), educational attainment (not a college graduate vs college graduate), employment status (unemployed vs unemployed), monthly household income $(<14,000$ PHP vs more than 14,000), use of alcohol (no vs yes), cigarette smoking (no vs yes), sexual preference (heterosexual vs homosexual), use of protective methods (no vs yes), extent of disclosure (undisclosed to any other person vs disclosed to another person), enrolment in other support groups (no vs yes), anti-retroviral therapy (not on anti-retroviral therapy vs on anti-retroviral therapy) were presented as frequencies and percentages.

Binary logistic analysis and stepwise regression analysis using backwards elimination was done using anxiety alone, depression alone, and mixed diagnosis (anxiety or depression) as a dependent variable to investigate the correlates of anxiety and depressive symptoms. Independent variables were binary in nature. The independent variables in the regression models were: sex, civil status, highest educational attainment, employment status, monthly household income, use of alcohol, cigarette smoking, use of illicit drugs, sexual preference, use of protective/barrier methods, extent of disclosure, enrolment in other support groups, and anti-retroviral therapy. CD4 levels were dichotomized as less than 200 cells $/ \mathrm{mL}$ vs 200 or more cells $/ \mathrm{mL}$ and age was also dichotomized as $<30$ years old vs $>30$ years old or more and were both included as independent variables in the analysis. Statistics were presented as odds ratio with $95 \%$ confidence intervals. 


\section{Ethical considerations}

$\mathrm{HIV}$ diagnosis is associated with significant social stigma. All records dealing with HIV status were treated with strict confidentiality in accordance with the provision of Republic Act 8504 (Philippine AIDS Law). Personnel who handled identifying data were restricted to clinical staff of the S.A.G.I.P. Unit and the investigators. The personnel who took the informed consent were GCP-certified and signed a confidentiality agreement. All collected questionnaires were kept in the clinic premises and research office. Only the first page of the case report form contained identifying data, with subsequent pages containing coded data. Databases were deidentified using only coded numerical identifiers.

Patient participation/involvement in the study was limited to answering questions on demographic data (1 minute), selfadministration of the HADS-P questionnaire (2-5 minutes), and provision of answers in a quick interview regarding behavioral and psychosocial parameters (1-2 minutes).

Once a diagnosis of anxiety or depression was made, the patient was referred accordingly to the Department of Psychiatry and Behavioral Sciences for further management.

The University of the Philippines Manila Research Ethics Board (UPM REB) conducted ethical review of the study protocol.

\section{RESULTS}

Demographic, socioeconomic, behavioral, psychosocial and health characteristics of the study population are shown in Table 1. Most the study participants were male (97.84\%). The mean age of the study participants was 31 years (range 18-57, SD 6.580). Participants were mostly single (88.49\%), college graduates (70.74\%), and employed (68.82\%) with monthly income of less than minimum wage per month of 14,000 PHP (56.83\%). Participants were mostly homosexual (83.45\%), non-alcoholic beverage drinkers (52.27\%), nonsmokers (80.10\%), non-users of illicit drugs (97.36\%), and users of barrier/protective methods during sexual intercourse (82.49\%). Majority of the patients disclosed their conditions with at least one other person (89.93\%), usually parents or the siblings. Only 11.03\% were enrolled in HIV/AIDS support groups such as the Positive Action Foundation Philippines, Inc. (PAFPI), The Red Ribbon (TRR), and the Pinoy Plus Association, Inc. Most participants (86.81\%) were currently ongoing ART with a regimen consisting of lamivudine, tenofovir/zidovudine, and efavirenz. Mean CD4 count was 307.73 (SD 220.82, range 3-1368) with $36.93 \%$ of the study participants with CD4 counts of less than 200 cells/ $\mathrm{mL}$. The number of cases and percent distribution of anxiety, depression, and mixed diagnosis (anxiety or depression) according to socio-demographic and clinical characteristics are outlined in Table 2 . The prevalence of symptoms of anxiety was $10.1 \%(0.072-0.130)$ and that for depression was $3.1 \%$ (0.014-0.048). The prevalence of mixed diagnosis (anxiety or depression) was $10.8 \%(0.078-0.138)$.
Table 1. Demographic, socioeconomic, behavioral, psychosocial, and health characteristics of the study population

\begin{tabular}{|c|c|}
\hline & $\begin{array}{l}\text { Frequency (\%) } \\
{[n=417]}\end{array}$ \\
\hline $\begin{array}{c}\text { Age, years } \\
<30\end{array}$ & $215(51.56)$ \\
\hline Sex & \\
\hline Male & $408(97.84)$ \\
\hline $\begin{array}{c}\text { Civil status } \\
\text { Single }\end{array}$ & $369(88.49)$ \\
\hline $\begin{array}{c}\text { Educational attainment } \\
\text { College graduate }\end{array}$ & $295(70.74)$ \\
\hline $\begin{array}{l}\text { Employment status } \\
\text { Unemployed }\end{array}$ & 130 (31.18) \\
\hline $\begin{array}{l}\text { Monthly household income } \\
\leq 14,000 \mathrm{PhP}\end{array}$ & $237(56.83)$ \\
\hline Use of alcohol & 199 (47.72) \\
\hline Cigarette smoking & $83(19.90)$ \\
\hline Use of illicit drugs & $11(2.64)$ \\
\hline $\begin{array}{r}\text { Sexual preference } \\
\text { Homosexual }\end{array}$ & 348 (83.45) \\
\hline Use of protective/barrier methods & 344 (82.49) \\
\hline Extent of disclosure & \\
\hline $\begin{array}{l}\text { No disclosure } \\
\text { Disclosed to another person }\end{array}$ & $\begin{array}{l}42(10.07) \\
375(89.93)\end{array}$ \\
\hline Enrolment in other support groups & $46(11.03)$ \\
\hline $\begin{array}{l}\text { Anti-retroviral therapy } \\
\text { Ongoing ART }\end{array}$ & $362(86.81)$ \\
\hline $\begin{array}{l}\text { CD4 count } \\
<200\end{array}$ & $154(36.93)$ \\
\hline HADS - P Anxiety & $42(10.07)$ \\
\hline HADS - P Depression & $13(3.12)$ \\
\hline HADS - P Anxiety or Depression & $45(10.79)$ \\
\hline
\end{tabular}

The significance of the main effects of the different independent variables on anxiety, depression, and mixed diagnosis was determined by univariate analysis (Appendix D). The process should begin with a univariate analysis to have an idea of the nature of strength of association of each independent variables and the outcome variable. Univariate test of any variable resulting to a pralue $\leq 0.25$ was considered a candidate for the multivariable model.

Since some of the variables did not reach significance level $p$ value $\leq 0.25$ in the univariate analysis, a model that included significant variables was constructed. The variables included in the model were then subjected to multivariate logistic regression analysis. Using the stepwise backward selection, the results of the analysis is shown in Tables 3 to 5 . The significance level for addition of a variable in the model was 0.15 and the significance level for removal of a variable in the model was 0.2 .

\section{Correlates of anxiety}

The multiple logistic regression analysis identified the following variables as correlates of symptoms of anxiety (Table 3). Female sex is correlated with symptoms of anxiety $(\mathrm{OR}=7.82, \mathrm{CI} 1.03-59.49)$. Unemployed patients also reported more symptoms of anxiety $(\mathrm{OR}=1.76$, CI 0.90 3.42) than those employed. Other significant correlates of anxiety included cigarette smoking $(\mathrm{OR}=1.84$, CI 0.89 - 
Table 2. Number of cases and percent distribution of anxiety, depression and mixed diagnosis (anxiety or depression) among HIV patients in UP-PGH according to socio-demographic and clinical characteristics

\begin{tabular}{|c|c|c|c|}
\hline & $\begin{array}{c}\text { HADS - } \mathbf{P} \\
\text { Anxiety } \\
\text { number of cases (\%) }\end{array}$ & $\begin{array}{c}\text { HADS - } \mathbf{P} \\
\text { Depression } \\
\text { number of cases (\%) }\end{array}$ & $\begin{array}{c}\text { HADS - P } \\
\text { Anxiety or Depression } \\
\text { number of cases (\%) }\end{array}$ \\
\hline $\begin{aligned} \text { Age, } & \text { years } \\
& <30 \\
& \geq 30\end{aligned}$ & $\begin{array}{c}21(9.77) \\
21(10.40)\end{array}$ & $\begin{array}{l}7(3.26) \\
6(2.97) \\
\end{array}$ & $\begin{array}{l}23(10.70) \\
22(10.89)\end{array}$ \\
\hline $\begin{array}{l}\text { Sex } \\
\text { Male } \\
\text { Female }\end{array}$ & $\begin{array}{l}40(9.80) \\
2(22.22)\end{array}$ & $\begin{array}{c}13(3.19) \\
0\end{array}$ & $\begin{array}{c}43(10.54) \\
2(22.22)\end{array}$ \\
\hline $\begin{array}{l}\text { Civil status } \\
\text { Single } \\
\text { Married } \\
\end{array}$ & $\begin{array}{l}35(9.49) \\
7(14.58)\end{array}$ & $\begin{array}{c}11(2.98) \\
2(4.17)\end{array}$ & $\begin{array}{c}38(10.30) \\
7(14.58)\end{array}$ \\
\hline $\begin{array}{l}\text { Educational attainment } \\
\text { Not college graduate } \\
\text { College graduate }\end{array}$ & $\begin{array}{c}14(11.48) \\
28(9.49)\end{array}$ & $\begin{array}{c}3(2.46) \\
10(3.39)\end{array}$ & $\begin{array}{l}14(11.48) \\
31(10.51)\end{array}$ \\
\hline $\begin{array}{l}\text { Employment status } \\
\text { Unemployed } \\
\text { Employed }\end{array}$ & $\begin{array}{c}18(13.85) \\
24(8.36)\end{array}$ & $\begin{array}{l}7(5.38) \\
6(2.09) \\
\end{array}$ & $\begin{array}{c}21(16.15) \\
24(8.36)\end{array}$ \\
\hline $\begin{array}{l}\text { Monthly household income, } \\
\quad \leq 14,000 \mathrm{PhP} \\
>14,000 \mathrm{Php}\end{array}$ & $\begin{array}{l}24(10.13) \\
18(10.00)\end{array}$ & $\begin{array}{l}8(3.38) \\
5(2.78)\end{array}$ & $\begin{array}{l}27(11.39) \\
18(10.00)\end{array}$ \\
\hline $\begin{array}{l}\text { Use of alcohol } \\
\text { No } \\
\text { Yes } \\
\end{array}$ & $\begin{array}{c}20(9.17) \\
22(11.06)\end{array}$ & $\begin{array}{l}8(3.67) \\
5(2.51) \\
\end{array}$ & $\begin{array}{l}22(10.09) \\
23(11.56) \\
\end{array}$ \\
\hline $\begin{array}{l}\text { Cigarette smoking } \\
\text { No } \\
\text { Yes } \\
\end{array}$ & $\begin{array}{c}29(8.68) \\
13(15.66) \\
\end{array}$ & $\begin{array}{c}10(2.99) \\
3(3.61)\end{array}$ & $\begin{array}{c}30(8.98) \\
15(18.07) \\
\end{array}$ \\
\hline $\begin{array}{l}\text { Use of illicit drugs } \\
\text { No } \\
\text { Yes }\end{array}$ & $\begin{array}{c}41(10.10) \\
1(9.09) \\
\end{array}$ & $\begin{array}{c}13(3.20) \\
0 \\
\end{array}$ & $\begin{array}{c}44(10.84) \\
1(9.09)\end{array}$ \\
\hline $\begin{array}{c}\text { Sexual preference } \\
\text { Heterosexual } \\
\text { Homosexual }\end{array}$ & $\begin{array}{c}2(2.90) \\
40(11.49)\end{array}$ & $\begin{array}{c}1(1.45) \\
12(3.45)\end{array}$ & $\begin{array}{c}3(4.35) \\
42(12.07)\end{array}$ \\
\hline $\begin{array}{l}\text { Use of protective/barrier methods } \\
\text { No } \\
\text { Yes }\end{array}$ & $\begin{array}{c}11(15.07) \\
31(9.01) \\
\end{array}$ & $\begin{array}{c}3(4.11) \\
10(2.91) \\
\end{array}$ & $\begin{array}{c}11(15.07) \\
34(9.88) \\
\end{array}$ \\
\hline $\begin{array}{l}\text { Extent of disclosure } \\
\text { No disclosure } \\
\text { Disclosed to another person }\end{array}$ & $\begin{array}{l}6(14.29) \\
36(9.60)\end{array}$ & $\begin{array}{c}3(7.14) \\
10(2.67)\end{array}$ & $\begin{array}{c}6(14.29) \\
39(10.40)\end{array}$ \\
\hline $\begin{array}{l}\text { Enrolment in other support groups } \\
\text { No } \\
\text { Yes }\end{array}$ & $\begin{array}{l}37(9.97) \\
5(10.87)\end{array}$ & $\begin{array}{c}11(2.96) \\
2(4.35)\end{array}$ & $\begin{array}{c}39(10.51) \\
6(13.04) \\
\end{array}$ \\
\hline $\begin{array}{l}\text { Anti-retroviral therapy } \\
\text { Not on ART } \\
\text { Ongoing ART } \\
\end{array}$ & $\begin{array}{l}6(10.91) \\
36(9.94) \\
\end{array}$ & $\begin{array}{c}1(1.82) \\
12(3.31)\end{array}$ & $\begin{array}{c}6(10.91) \\
39(10.77) \\
\end{array}$ \\
\hline $\begin{aligned} \text { CD4 } & \text { count } \\
& <200 \\
& \geq 200\end{aligned}$ & $\begin{array}{c}16(10.39) \\
26(9.89)\end{array}$ & $\begin{array}{l}5(3.25) \\
8(3.04)\end{array}$ & $\begin{array}{l}17(11.04) \\
28(10.65)\end{array}$ \\
\hline
\end{tabular}

3.79), and homosexuality (OR = 7.64, CI 1.36-42.74). Lastly, study participants who did not use any protective methods during sexual intercourse were likely to experience symptoms of anxiety (OR = 1.81, CI 0.84-3.93).

\section{Correlates of depression}

The multiple logistic regression analysis identified two significant correlates of depressive symptoms (Table 4). Unemployment was positively correlated with symptoms of depression $(\mathrm{OR}=2.79$, CI 0.91-8.54). Those who did not disclose their status either with family or friends were more likely to experience depression $(\mathrm{OR}=3.04$, CI 0.79-11.67).

\section{Correlates of mixed diagnosis (anxietyor depression)}

The multiple logistic regression analysis identified the following variables as correlates of either anxiety or depression (Table 5). Again, those who were unemployed were noted to have more symptoms of either anxiety or depression $(\mathrm{OR}=$ 2.09, CI 1.10-3.96). Smokers who participated in the study also experienced more symptoms of anxiety or depression compared with their counterparts $(\mathrm{OR}=2.14$, CI 1.08$4.25)$. Other significant correlates of symptoms of anxiety or depression were homosexuality $(\mathrm{OR}=3.14$, CI 0.92-10.65) and non-use of protective methods during sexual intercourse $(\mathrm{OR}=1.65$, CI 0.77-3.53). 
Table 3. Results of the multiple logistic regression (anxiety)

\begin{tabular}{lcc} 
& OR $(95 \% \mathrm{CI})$ & p value \\
Sex (Female) & $7.82(1.03-59.49)$ & 0.047 \\
Employment status (Unemployed) & $1.76(0.90-3.42)$ & 0.097 \\
Cigarette smoking & $1.84(0.89-3.79)$ & 0.098 \\
Sexual preference (Homosexual) & $7.64(1.36-42.74)$ & 0.021 \\
Non-user of protective methods & $1.81(0.84-3.93)$ & 0.130 \\
\hline
\end{tabular}

Table 4. Results of the multiple logistic regression (depression)

\begin{tabular}{lcc}
\hline $\begin{array}{c}\text { Employment status } \\
\text { Unemployed }\end{array}$ & $2.79(0.91-8.54)$ & 0.072 \\
\hline $\begin{array}{c}\text { Extent of disclosure } \\
\text { No disclosure }\end{array}$ & $3.04(0.79-11.67)$ & 0.106 \\
\hline
\end{tabular}

Table 5. Results of the multiple logistic regression (mixed diagnosis)

\begin{tabular}{lcc}
\hline & OR $(95 \% \mathrm{Cl})$ & p value \\
Employment status (Unemployed) & $2.09(1.10-3.96)$ & 0.024 \\
Cigarette smoking & $2.14(1.08-4.25)$ & 0.030 \\
Sexual preference (Homosexual) & $3.14(0.92-10.65)$ & 0.067 \\
Non-user of protective methods & $1.65(0.77-3.53)$ & 0.195 \\
\hline
\end{tabular}

\section{DISCUSSION}

This study is one of the few researches that measure the prevalence of anxiety and depression among patients with chronic diseases being seen in the outpatient setting. The prevalence of anxiety, depression, and anxiety or depression (10.1\%, 3.1\%, and $10.8 \%$, respectively) noted in this study were lower than those cited in other studies. ${ }^{12,14-16}$ It was also not congruent with a study by De Guzman in 2013 involving Filipino patients with chronic diseases, which showed a prevalence of anxiety and depression of $14.3 \%$ and $26.9 \%$, respectively. ${ }^{5}$ However, the said study focused on inpatients, which may have explained the higher prevalence of anxiety and depression.

The significant variables that were correlated with anxiety and mixed diagnosis were cigarette smoking, homosexuality, and non-use of protective methods during sexual intercourse. Unemployment was a significant variable correlated in anxiety, depression, and mixed diagnosis. Female sex was a significant variable for anxiety alone while non-disclosure of status to either family or friends was positively correlated to symptoms of depression.

The finding of smoking being related to anxiety, depression, and mixed diagnosis was also consistent with a large population study done in Europe in 2008 (The HUNT Study). ${ }^{17}$ The HUNT Study showed smoking was strongest in co-morbid anxiety and depression, followed by anxiety and only marginal in depression. Also, homosexuality was a very significant factor related to anxiety and this was also similar to the findings of a meta-analysis which showed that gays, lesbians, and bisexuals have a 1.5 times risk of having anxiety and/or depression disorders over a period of 12 months or a lifetime. ${ }^{18}$ Currently, there are no studies supporting that non-use of protective barrier during sexual intercourse can increase anxiety and depression symptoms and this may serve as a topic for future researches.

The finding of unemployment being a significant factor in patients suffering from anxiety, depression, and mixed diagnosis is in agreement with a study done in 2003 which showed that unemployed patients are 2.53 times more likely to have symptoms of anxiety and or anxiety disorder (95\% CI 2.37-2.69). ${ }^{19}$

Female sex, being a positive correlate of symptoms of anxiety, can be explained by the higher prevalence of this condition among women that was also observed in a report on the gender differences of mental health disorders between males and females in the Philippines. It reported that women are two times more prone to having anxiety disorders which can be explained by their unique reproductive function (ie, onset of menses, labor and pregnancy and perimenopausal experiences) as well as gender role socialization (in a hierarchical social structure, women are assigned many roles, namely; domestic, productive, and community activities which they should carry out all at the same time while men are only assigned with productive roles). ${ }^{19}$

Wiener et al in 2000, have shown that HIV patients who were able to disclose their status to more people enjoy more social support. ${ }^{20}$ Several studies have also shown that disclosure of HIV status is associated with lower levels of depression. The result of this study is in agreement with these previous studies. ${ }^{21,22}$ Our study did not find an association between enrolment in a support group and fewer symptoms of anxiety and depression. This is contrary to a research done in Thailand in 2009, which concluded that participation in a support group was associated with fewer symptoms of depression. ${ }^{23}$ This may be due to the significantly low number of individuals enrolled in a support group that was noted in this study (11.03\%).

The wide confidence interval noted in the two variables, namely female sex (CI1.03-59.49; anxiety) and homosexuality (CI 1.36-42.74; anxiety and 0.92-10.65; mixed diagnosis) can be explained by the few number of females $(2 \%)$ and considerably more number of homosexuals participating in this study (84\%). It should also be noted that the mean CD4 counts of patients is relatively high $(307.73$ cells $/ \mathrm{mL})$, and this is most likely due to the significantly higher number of patients enrolled who are currently on anti-retrovirals.

The study has several limitations; firstly, the study participants were drawn only from those patients seen in the UP-PGH SAGIP Unit, therefore the data gathered here are underestimates of the true prevalence of HIV patients suffering from anxiety and depression all over the country. Secondly, since some of the data gathered were based on selfreported information, the measures may not be completely accurate. Lastly, a cross sectional study cannot definitely establish the association between the several factors noted and symptoms of anxiety and depression even if these were significant. 


\section{CONCLUSIONS AND RECOMMENDATIONS}

The prevalence of symptoms of anxiety, depression, and mixed diagnosis (anxiety or depression) in this study population was $10.1 \%, 3.1 \%$, and $10.8 \%$, respectively. The incessant increase in the number of new cases of HIV may also imply that more patients will likely suffer from affective disorders, hence the prevalence noted in this study are expected to rise as well. Even if this is the most probable scenario, there are currently no established guidelines in screening and monitoring for anxiety and depression in this vulnerable group. HADS-P, a simple and practical tool, can be used to address this gap in the management of people living with HIV (PLHIV), since this self-administered questionnaire only takes about two to five minutes to complete and can be conveniently used in any clinic. Likewise, screening for affective disorders is an emerging important aspect of managing PLHIV, since the presence of anxiety and depression is linked to low compliance to medications leading to poorer health outcomes.

Better working opportunities (eg, less discrimination, equal prospects, etc) should be provided to address unemployment among PLHIV, since it is a significant factor that increases the risk of developing anxiety and depression. Also, since cigarette smoking and non-use of protective methods during intercourse were positively correlated with symptoms of anxiety and mixed diagnosis, advice should be given to patients seen in the clinics regarding the importance of smoking cessation and use of protective barriers during intercourse.

Clearly, there is a necessity to address mental health in the context of the over-all well-being of PLHIV so that compliance to treatment is enhanced and their quality of life improved.

\section{Statement of Authorship}

All authors have approved the final version submitted.

\section{Author Disclosure}

All the authors declared no conflict of interest.

\section{Funding Source}

This paper was partially funded by the Philippine General Hospital and the authors.

\section{REFERENCES}

1. UNAIDS Global Report: UNAIDS Fact Sheet [Online]. [cited 2017 Jul]. Available from http://www.unaids.org/en/resources/fact-sheet.

2. Philippine National Aids Council. 2016 Global AIDS Response Progress Reporting: Country Progress Report Philippines [Online]. [cited 2016]. Available from http://www.unaids.org/en/ regionscountries/countries/philippines.
3. Destura RV, Berba RP, Mendoza MT, et al. Profile of HIV/AIDS patients at the Philippine General Hospital: revisiting 9 Years of clinical experience. Phil J Microbiol Infect Dis. 2003; 32:11-21.

4. Zigmond AS, Snaith RP. The hospital anxiety and depression scale. Acta Psychiatr Scand. 1983; 67(6):361-70.

5. De Guzman ML. A validation of the hospital anxiety and depression scale (HADS) in the medically ill. Acta Med Philipp.2013;47(3):53-62.

6. Mathers CD, Loncar D. Projections of global mortality and burden of disease from 2002-2030. PLoS Med. 2006; 3(11):e442.

7. Gupta R, Dandu M, Packel L, et al. Depression and HIV in Botswana: a population-based study on gender-specific socio-economic and behavioural correlates. PLoS One. 2010; 5(12): e14252.

8. Smit J, Myer L, Middlekoop K, et al. Mental health and sexual behaviours in a South African township: a community-based crosssectional study. Public Health. 2006; 120(6):534-42.

9. Meade CS, Sikkema KJ. HIV risk behavior among adults with severe mental illness: a systematic review. Clin Psychol Rev. 2005; 25(4):433-57.

10. Boarts JM, Buckley-Fischer BA, Armelie AP, Bogart LM, Delahanty DL. The impact of HIV diagnosis-related vs. non-diagnosis related trauma on PTSD, depression, medication adherence, and HIV disease markers. J Evid Based Soc Work. 2009; 6(1):4-16.

11. Hand GA, Phillips KD, Dudgeon WD. Perceived stress in HIVinfected individuals: Physiological and psychological correlates. AIDS Care. 2006; 18(8):1011-7.

12. Pappin, M, Wouters E, Booysen FL. Anxiety and depression amongst patients enrolled in a public sector antiretroviral treatment programme in South Africa: a cross-sectional study. BMC Public Health. 2012; 12:244-52.

13. Horberg MA, Silverberg MJ, Hurley LB, et al. Effects of depression and selective serotonin reuptake inhibitor use on adherence to highly active antiretroviral therapy and on clinical outcomes in HIV-infected patients. J Acquir Immune Defic Syndr. 2008; 47(3):384-90.

14. Asch SM, Kilbourne AM, Gifford AL, et al. Underdiagnosis of depression in HIV: who are we missing. J Gen Intern Med. 2003; 18(6):450-60.

15. Shacham E, Morgan J, Önen NF, Taniguchi T, Overton ET. Screening anxiety in the HIV clinic. AIDS Behav. 2012; 16(8):2407-13.

16. Reyes MVT, Reyes B. Engendering Philippine mental health. Speech presented at; 2004; Mandaluyong City Philippines.

17. Mykletun A, Overland S, Aaro LF, Liabo HM, Stewart R. Smoking in relation to anxiety and depression: evidence from a large population survey: The HUNT Study. Eur Psychiatry. 2008; 23(2):77-84.

18. King M, Semlyen J, Tai SS, et al. A systematic review of mental disorder, suicide, and deliberate self harm in lesbian, gay and bisexual people. BMC Psychiatry. 2008; 8:70-86.

19. Comino EJ Harris E, Chey T, et al. Relationship between mental health disorders and unemployment in Australian adults. Aust N Z J Psychiatry. 2003; 37(2):230-5.

20. Wiener LS, Battles HB, Heilman N. Public disclosure of a child's HIV infection: impact on children and families. AIDS Patient Care STDS. 2000; 14(9):485-97.

21. Hays RB, McKusick L, Pollack L, Hilliard R, Hoff C, Coates TJ. Disclosing HIV seropositivity to significant others. AIDS. 1993; 7(3):425-31.

22. Armistead L, Morse E, Forehand R, Morse P, Clark L. AfricanAmerican women and self-disclosure of HIV infection: rates, predictors, and relationship to depressive symptomatology. AIDS Behav. 1999;3(3):195-204

23. Li L, Lee SL, Thammawijaya P, Jiraphongsa C, Rotheram-Borus MJ. Stigma, social support, and depression among people living with HIV in Thailand. AIDS Care. 2009; 21(8):1007-13. 


\section{APPENDICES}

Appendix A. Workflow

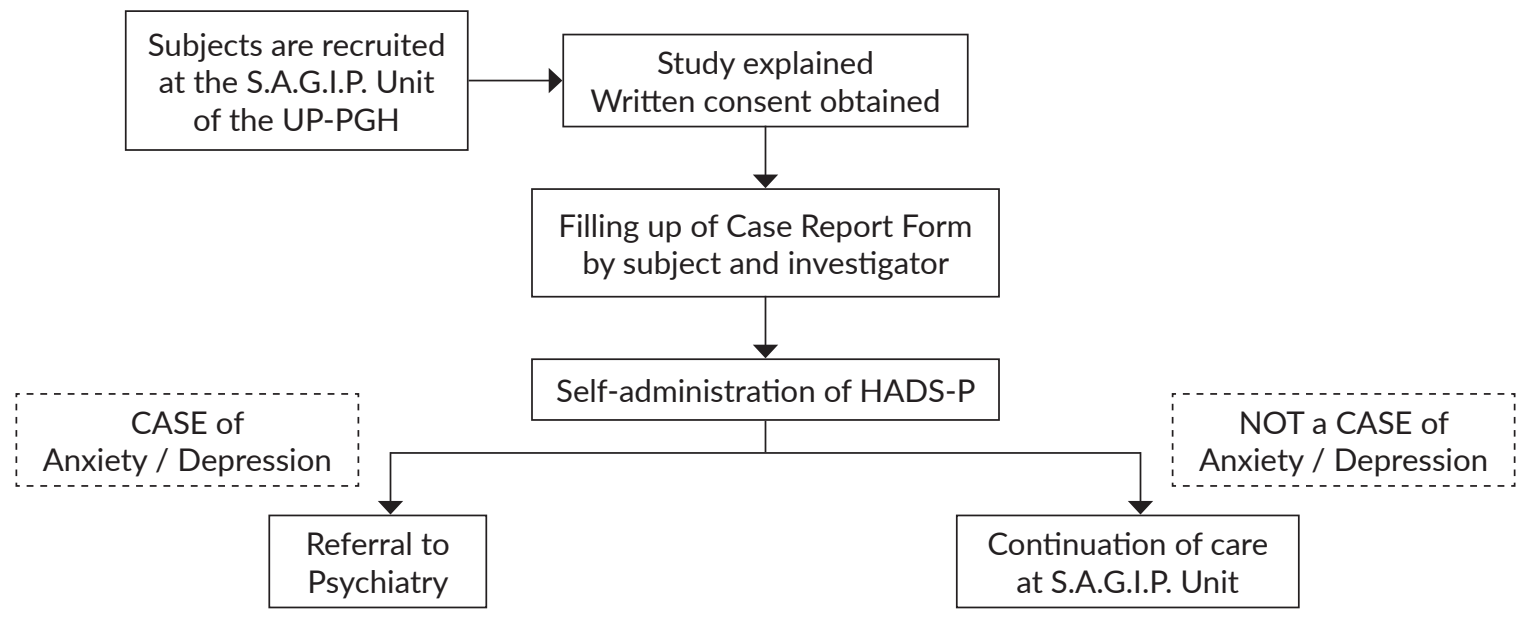

Appendix B. Data Collection Form

For study personnel use only

ID Code:

Date of recruitment:

Part I: Demographic, Socioeconomic, Behavorial, Psychosocial and Health

Direksyon: Punan ang mga patlang ng mga kasagutan sa mga tanong bilang 1.2 hanggang 1.12. Lagyanng $\mathrm{X}$ (ekis) ang mga pagpipilian na tugma sa iyon gsagot. Walang ibang tao ang makakaalam ng mga kasagutan kundi ang mga nagsasagawa ng pagaaral. Maraming salamat.

DEMOGRAPHICS (to be kept in a separate sheet with the code. No identifying data other than the code will be placed on all clinical questionnaires and results forms)

1.1 "Code" \# (huwag sagutan):

1.2. Edad:

1.3. Lugar ng kapanganakan:

1.4. Nasyonalidad:

1.5. Kasarian: [ ] Male [ ] Female

1.6. Tirahan sa Metro Manila (kung mayroon):

1.7. Probinsya (kung mayroon):

1.8. Katayuan: [ ]"Single" [ ] Kasal/May "ka-live in"

1.9. Nakatapos ng kolehiyo? [ ]Oo [ ] Hindi

1.10. May trabaho?: [ ] Wala [ ] Mayroon,

1.11. Kung mayroong trabaho, ano ito?

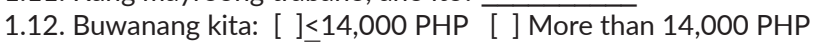


Part II. Hospital Anxiety and Depression Scale-Pilipino Version (HADS-P)

(Adapted from M. De Guzman, UP-PGH Department of Psychiatry and Behavioral Sciences)

Direksyon:

Alam ng mga doktor na may mahalagang papel ang damdamin natin sa maraming sakit. Kung alam ng iyong doktor ang inyong nararamdaman, mas matutulungan niya kayo.

Ang palatanungang ito ay ginawa para tulungan ang iyong doktor na malaman ang inyong nararamdaman.

Sagutin ang bawat tanong base sa pinakamalapit sa inyong nararamdaman sa nakaraang linggo. Huwag masyadong magtagal sa pagsagot; ang inyong unang reaksyon ay mas malamang na tama kaysa mas matagal na pinag-isipang sagot.

Isa lamang ang isagot sa bawat tanong, lagyan ng markang $\mathrm{X}$ (ekis) sa tapat ng katagang iyong napili.

\begin{tabular}{|l|l|l|}
\hline D & 1. & Pakiramdam ko parang pinapabagal ako: \\
\hline 3 & & Halos lagi lagi \\
\hline 2 & & Napakadalas \\
\hline 1 & & Minsan \\
\hline 0 & & Hinding hindi \\
\hline & 2. & $\begin{array}{l}\text { Ikinasasaya ko pa rin ang mga bagay na dati ko nang } \\
\text { ikinasasaya: }\end{array}$ \\
\hline 0 & & Katulad din ng dati \\
\hline 1 & & Hindi na kasing dalas \\
\hline 2 & & Konti lang \\
\hline 3 & & Halos hindi na \\
\hline & 3. & Nawalan na ako ng interes sa aking hitsura: \\
\hline 3 & & Talaga \\
\hline 2 & & Hindi ako nangangalaga ng dapat \\
\hline 1 & & Pwedeng hindi ako mag-alaga ng nararapat \\
\hline 0 & & Pinapangalagaan ko pa rin ito katulad ng dati \\
\hline & 4. & $\begin{array}{l}\text { Kaya ko pang tumawa at mapansin ang } \\
\text { nakakatuwang bahagi sa mga bagay bagay: }\end{array}$ \\
\hline 0 & & Lagi lagi tulad ng dati \\
\hline 1 & & Mas madalang nang konti kaysa dati \\
\hline 2 & & Hindi na katulad ng dati \\
\hline 3 & & Hinding hindi \\
\hline & 5. & Masaya akong umaasa sa mga bagay bagay: \\
\hline 0 & & Kasing dalas ng nakagawian ko \\
\hline 1 & & Di kasing dalas ng nakagawian ko \\
\hline 2 & & Mas madalang kaysa nakagawian ko \\
\hline 3 & & Halos hindi na \\
\hline & 6. & Masaya ang aking pakiramdam \\
\hline 3 & & Hindi kailanman \\
\hline 2 & & Madalang \\
\hline 1 & & Paminsan minsan \\
\hline 0 & & Kadalasan \\
\hline & 7. & $\begin{array}{l}\text { Kaya kong maaliw sa isang magandang libro o } \\
\text { programa sa radyo o TV: }\end{array}$ \\
\hline 0 & & Madalas \\
\hline 1 & & Paminsan minsan \\
\hline 2 & & Madalang \\
\hline
\end{tabular}

\begin{tabular}{|l|l|l|}
\hline A & 8. & Naliligalig at punung puno na ako: \\
\hline 3 & & Mas madalas kaysa hindi \\
\hline 2 & & Madalas \\
\hline 1 & & Paminsan minsan \\
\hline 0 & & Hinding hindi \\
\hline & 9. & $\begin{array}{l}\text { Para akong natatakot na may nararamdamang } \\
\text { sobrang nerbyos: }\end{array}$ \\
\hline 0 & & Hinding hindi \\
\hline 1 & & Paminsan minsan \\
\hline 2 & & Medyo madalas \\
\hline 3 & & Madalas na madalas \\
\hline & 10. & Para akong natatakot na may mangyayaring masama: \\
\hline 3 & & Lagi lagi at medyo lang \\
\hline 2 & & Palagi pero di gaanong malala \\
\hline 1 & & Konti, pero di ako nag aalala \\
\hline 0 & & Hinding hindi \\
\hline & 11. & $\begin{array}{l}\text { Hindi ako mapakali na parang gusto kong may } \\
\text { pinagkakaabalahan: }\end{array}$ \\
\hline 3 & & Talagang madalas \\
\hline 2 & & Medyo madalas \\
\hline 1 & & Di naman gaano \\
\hline 0 & & Hinding hindi \\
\hline & 12. & Pag-aalala ang nasa isip ko: \\
\hline 3 & & Madalas na madalas \\
\hline 2 & & Madalas \\
\hline 1 & & Di gaanong madalas \\
\hline 0 & & Konting konti \\
\hline & 13. & Bigla akong nakakaramdam ng pagkasindak: \\
\hline 3 & & Madalas na madalas \\
\hline 2 & & Medyo madalas \\
\hline 1 & & Di gaanong madalas \\
\hline 0 & & Hinding hindi \\
\hline & 14. & Kaya kong umupo nang kumportable at mag-relaks: \\
\hline 0 & & Madalas \\
\hline 1 & & Paminsan minsan \\
\hline 2 & & Madalang \\
\hline 3 & & Hinding hindi \\
\hline
\end{tabular}

Maraming salamat sa iyong oras! 
Part III: Socioeconomic, Behavorial, Psychosocial and Health Data

BEHAVIORAL PARAMETERS

2.1. Use of alcohol? [ ] No [ ] Yes

2.2. Cigaratte smoking? [ ] No [ ] Yes

2.3. Use of illicit drug use? [ ] No [ ] Yes

2.4. Sexual preference? [ ] Heterosexual [ ] Homosexual

2.5. Use of protective/barrier methods? (e.g. condoms)

[ ] No

[ ] Yes

PSYCHOSOCIAL PARAMETERS

3.1. Extent of disclosure of HIV diagnosis:

[ ] I haven't disclosed my HIV diagnosis with any other person

[ ] I have disclosed my HIV diagnosis with another person/other people

Please state your relationship with these people:

3. 2. Are you enrolled in any HIV support group?

[ ] No

[ ] Yes. If yes, what groups?

HEALTH PARAMETERS (For the study personnel only, please do not fill out)

4.1. Date of HIV Diagnosis (MM/DD/YYYY):

4.2. Currently ongoing ART?

[ ] No

[ ] Yes. If yes, what drugs?

4.3. Latest CD4 count:

4.4. Latest HIV RNA level: 


\title{
CONSENT FORM \\ (English)
}

Good day. You are being invited to participate in a study entitled "MEASUREMENT OF ANXIETY AND DEPRESSION AMONG HIV PATIENTS SEEN IN THE UP-PHILIPPINE GENERAL HOSPITAL USING THE HOSPITAL ANXIETY AND DEPRESSION SCALE - PILIPINO VERSIONS (HADS-P)" that is being conducted by Dr. Kenneth G. Samala and Dr. Deonne Thaddeus V. Gauiran. Participation in this study is purely voluntary and is not required. You will not be penalized in any way if you elect not to participate in this study. By signing this document, you warrant that you are giving your full informed consent and that the following items have been explained to your satisfaction.

1. The objective of this study is measure the prevalence of anxiety and depression among HIV patients seen in the UP- Philippine General Hospital using the Hospital Anxiety and Depression Scale - Pilipino version (HADS-P).The study also aims to assess the impact of the following variables on symptoms of anxiety and depression: like demographic (age, sex and civil status), socio-economic (highest educational attainment, employment status and monthly household income), behavioral (alcohol, cigarette smoking, use of illicit drugs, sexual preference and use of protective/barrier methods), psychosocial (extent of disclosure and enrolment in other support groups) and health (use of anti-retroviral therapy and latest CD4 count).

2. Information gathered from this study will be held in strict confidence, and no identifying information will be given out in the final report.

3. You will be asked to fill out a data form as completely as possible. This form will include basic demographic information, highest educational attainment, employment status, monthly household income, use of alcohol, cigarette smoking, use of illicit drugs, sexual preference, use of protective/barrier methods, extent of disclosure and enrolment in other support groups. At least 400 participants will be recruited for this study which will start from June 2013 until December 2014.

4. Consent can be withdrawn at any time, and will not result in any consequences.

5. Benefits of participating in this study include knowing if you are at risk or if you have symptoms of anxiety and depression so a prompt and immediate referral to a psychiatric specialist can be facilitated. Also, the data, which will be generated in the study, will be used to establish a multi-specialist approach to the management of HIV with emphasis on the participation of psychiatrists.

6. Risks of participating in this study are minimal since there are no interventions or procedures. For HIV positive patients, a diagnosis of HIV is associated with possible social stigma, and so strict confidentiality regarding your diagnosis will be observed at all times.

7. No financial compensation is offered for participation, other than free access to expert care as outlined in item 5.

8. Any questions or reservations regarding the study at any time can be addressed to Dr. Kenneth G. Samala, Department of Medicine, Philippine General Hospital at telephone number 09176302265. Should you have questions regarding patients rights and grievances, you may contact the PGH-EHRO Review Panel through:

\author{
Dr. Jacinto Blas Mantaring \\ Adress: 2/F Paz Mendoza \\ 547 Pedro Gil Street \\ Ermita 1000 Manila \\ Email: upmreb@post.upm.edu.ph \\ Telephone: +63 2 522-2684 \\ Mobile: +639273264910 / +639153080212
}

Thank you very much for your attention. If you wish to participate in this study, please affix your signature below and date the document. You will be given a copy of this consent form for your files.

PRINT NAME AND SIGN

DATE OF SIGNATURE

CONSENT TAKEN BY:

PRINT NAME AND SIGN 


\title{
CONSENT FORM \\ (Filipino)
}

Magandang araw! Ikaw ay malugod na inaanyayahan na makilahok sa pag-aaral na pinamagatang "MEASUREMENT OF ANXIETY AND DEPRESSION AMONG HIV PATIENTS SEEN IN THE UP-PHILIPPINE GENERAL HOSPITAL USING THE HOSPITAL ANXIETY AND DEPRESSION SCALE - PILIPINO VERSIONS (HADS-P)" na pinamumunuan nina Dr. Kenneth G. Samala at Dr. Deonne Thaddeus V. Gauiran. Ang iyong pagsali sa pag-aaral na ito ay di sapilitan at boluntaryo lamang. Walang anumang kaparusahan ang iyong makukuha kung ikaw man ay hindi sasali sa pag-aaral na ito. Sa iyong paglagda sa dokumentong ito, buong-puso kang pumapayag sa pagsali sa pag-aaral na ito at lahat ng mga alituntunin ng pag-aaral at lahat ng mga bagay sa dokumentong ito ay naipaliwanag sa iyo ng husto.

1. Ang layunin ng pag-aaral na ito ay malaman kung ilan sa mga pasyenteng may HIV na nakikita sa UP-PGH ang may depresyon gamit ang Hospital Anxiety and Depression Scale - Pilipino Version (HADS-P). Ang pag-aaral na ito ay nais din matukoy ang mga iba't-ibang bagay na maaaring makaapekto sa mga sintomas ng anxiety at depresyon tulad ng edad, lahi, kasarian, pagkakaroon ng asawa o wala, natapos sa pag-aaral, pagkakaroon ng trabaho, sahod kada buwan, pag-inom ng alak, paninigarilyo, paggamit ng ipinagbabawal na gamot, sekswal na oryentasyon, paggamit ng mga proteksyon kapag nakikipagtalik, pagbabahagi ng impormasyon tungkol sa iyong kalusugan sa iba at pagkakaroon ng mga support groups, paggamit ng gamot laban sa HIV, lebel ng CD4 at HIV RNA.

2. Ang lahat ng mga impormasyong makakalap sa pag-aaral na ito ay hindi malalaman ng iba at walang anumang bagay na nakapaloob sa mga resultang pag-aaral na ito ang magkakaroon ng kahit anumang kaugnayan sa iyo.

3. May ibibigay na data form kung saan hihingin mula sa mga kalahok ang mga demograpikong impormasyon at iba pang impormasyon tulad ng pinakamataas na antas na naabot sa pag-aaral, trabaho, kinikita ng pamilya sa isang buwan, pag-inom ng alak, paninigarilyo, paggamit ng pinagbabawal na mga gamot, sekswal na oryentasyon, paggamit ng mga protektibo o barrier methods tulad ng kondom, kung kanino na naibahagi ang estado ng iyong sakit na HIV at iyong partisipasyon sa mga HIV support groups. Ipinapakiusap na kumpletuhin ang mga sagot sa lahat ng mga tanong. Ikaw ay bibigyan ng "code number" nasiyang gagamitin para makilala ang mga datos na nakuha sa iyo. Walang anumang impormasyon na makakatukoy sa iyong pangalan o anuman na makakapakilala sa iyo ang ilalagay sa mga forms, kundi mga palatandaan lamang sa pamamagitan ng nasabing "code number." Hindi kukulang sa 400 katao ang aanyayahang sumali sa pag-aaral na ito.

4. Maaaring itigil ang paglahok sa pag-aaral na ito anumang oras na walang idudulot na anumang problema sa naging kalahok.

5. Kasama sa benepisyong matatamo sa pag-aaral na ito ay ang pag-alam kung mayroon kayong mga sintomas ng anxiety o depresyon. Sa pagka-alam nito, magkakaroon ng mas maagang referral sa ispesyalista ng psychiatry upang matugunan ang inyong mga sintomas. Ang mga resulta din ng pag-aaral na ito ay makakatulong sa pagtatag ng isang sistema na nakapaloob na ang kalusugang mental para sa mga pasyenteng may HIV.

6. Walang inaasahang peligro sa paglahok sa pag-aaral na ito dahil wala namang gagawin na pagtusok o operasyon.. Sa mga pasyenteng may-HIV, ang pagkakaroon ng HIV ay maaaring magdulotng tinatawag na "stigma". Upang maiwasan ang ganitong pangyayari, iingatan ng lubos ang lahat ng impormasyon na makapagtutukoy sa inyo bilang isang taong may-HIV kung sakali man malaman na mayroon kayong ganitong sakit.

7. Ang mga kalahok ay hindi makatatanggap ng anumang salapi sa pagsali sa pag-aaral na ito maliban sa libreng konsultasyon kagaya ng itinutukoy sa bilang 5.

8. Anumang katanungan at pagaalinlangang may kaugnayan sa pag-aaral na ito ay maaaring isangguni anumang oras kay Dr. Kenneth G. Samala, Department of Medicine, Philippine General Hospital sa telephone number 09176302265. Kung may katanungan tungkol sa mga karapatan ninyo bilang pasyente at mga hinaing maaaring makipagugnay sa UPMREB NIH Review Panel sa:

\author{
Dr. Jacinto Blas Mantaring \\ Adress: 2/F Paz Mendoza \\ 547 Pedro Gil Street \\ Ermita 1000 Manila \\ Email: upmreb@post.upm.edu.ph \\ Telephone: +63 2 522-2684 \\ Mobile: $+639273264910 /+639153080212$
}

Salamat ng marami sa iyong panahon. Kung gusto mong makilahok sa aming pag-aaral, mangyari lamang na lagdaan ito sa ibaba at ang petsa kung kalian ito nilagdaan. Ikaw ay makatatanggap ng sipi ng dokumentong ito para sa iyong kaalaman.

PANGALAN AT LAGDA

PETSA NG PAGLAGDA

ANG PAGPAYAG AY KINUHA NI:

PANGALAN AT LAGDA 
Anxiety and Depression among UP-PGH HIV Patients

Appendix D. Results of univariate analysis

\begin{tabular}{|c|c|c|c|c|c|c|}
\hline & \multicolumn{2}{|c|}{$\begin{array}{l}\text { HADS - P } \\
\text { Anxiety }\end{array}$} & \multicolumn{2}{|c|}{$\begin{array}{l}\text { HADS - P } \\
\text { Depression }\end{array}$} & \multicolumn{2}{|c|}{$\begin{array}{c}\text { HADS - P } \\
\text { Anxiety or Depression }\end{array}$} \\
\hline & OR $(95 \% \mathrm{Cl})$ & p-value & OR $(95 \% \mathrm{Cl})$ & p-value & OR $(95 \% \mathrm{Cl})$ & $\mathrm{p}$-value \\
\hline Age ( $<30$ years old) & $0.93(0.49-1.77)$ & 0.831 & $1.10(0.36-3.33)$ & 0.867 & $0.98(0.53-1.82)$ & 0.949 \\
\hline Sex (Female) & $2.63(0.53-13.08)$ & 0.238 & 1.00 & & $2.42(0.49-12.05)$ & 0.279 \\
\hline Civil status (Married) & $1.63(0.68-3.90)$ & 0.274 & $1.42(0.30-6.58)$ & 0.658 & $1.49(0.62-3.55)$ & 0.371 \\
\hline $\begin{array}{l}\text { Educational attainment } \\
\text { Not college graduates }\end{array}$ & $1.24(0.63-2.44)$ & 0.541 & $0.72(0.19-2.66)$ & 0.620 & $1.10(0.57-2.16)$ & 0.772 \\
\hline $\begin{array}{l}\text { Employment status } \\
\text { Unemployed }\end{array}$ & $1.76(0.92-3.37)$ & 0.088 & $2.66(0.88-8.09)$ & 0.084 & $2.11(1.13-3.95)$ & 0.019 \\
\hline $\begin{array}{l}\text { Monthly household income, } \\
\mathrm{PhP} \leq 14,000\end{array}$ & $1.01(0.53-1.93)$ & 0.966 & $1.22(0.39-3.80)$ & 0.728 & $1.16(0.62-2.17)$ & 0.650 \\
\hline Use of alcohol & $1.23(0.65-2.33)$ & 0.524 & $0.68(0.22-2.10)$ & 0.500 & $1.16(0.63-2.16)$ & 0.630 \\
\hline Cigarette smoking & $1.95(0.97-3.95)$ & 0.062 & $1.22(0.33-4.52)$ & 0.771 & $2.24(1.14-4.38)$ & 0.019 \\
\hline Non-user of illicit drugs & $1.12(0.14-9.00)$ & 0.913 & 1.00 & & $1.22(0.15-9.72)$ & 0.854 \\
\hline Sexual preference (Homosexual) & $4.35(1.03-18.44)$ & 0.046 & $2.43(0.31-18.99)$ & 0.398 & $3.02(0.91-10.04)$ & 0.071 \\
\hline Non-user of protective methods & $1.79(0.85-3.75)$ & 0.122 & $1.43(0.38-5.34)$ & 0.593 & $1.62(0.78-3.37)$ & 0.198 \\
\hline $\begin{array}{l}\text { Extent of disclosure } \\
\text { No disclosure }\end{array}$ & $1.57(0.62-3.98)$ & 0.342 & $2.81(0.74-10.63)$ & 0.129 & $1.44(0.57-3.62)$ & 0.444 \\
\hline Enrolment in other support groups & $1.10(0.41-2.96)$ & 0.849 & $1.49(0.32-6.93)$ & 0.613 & $1.28(0.51-3.20)$ & 0.603 \\
\hline $\begin{array}{l}\text { Anti-retroviral therapy } \\
\text { Ongoing ART } \\
\end{array}$ & $0.90(0.36-2.25)$ & 0.825 & $1.85(0.24-14.53)$ & 0.558 & $0.99(0.40-2.45)$ & 0.976 \\
\hline $\begin{array}{r}\text { CD4 count } \\
\geq 200 \\
\end{array}$ & $0.95(0.49-1.82)$ & 0.869 & $0.93(0.30-2.91)$ & 0.908 & $0.96(0.51-1.82)$ & 0.901 \\
\hline
\end{tabular}

